\title{
Boundary spanners, HRM practices, and reverse knowledge transfer: the case of Chinese cross-border acquisitions
}

Article

Accepted Version

Creative Commons: Attribution-Noncommercial-No Derivative Works 4.0

Liu, Y. and Meyer, K. E. (2020) Boundary spanners, HRM practices, and reverse knowledge transfer: the case of Chinese cross-border acquisitions. Journal of World Business, 55 (2). 100958. ISSN 1090-9516 doi:

https://doi.org/10.1016/j.jwb.2018.07.007 Available at https://centaur.reading.ac.uk/79414/

It is advisable to refer to the publisher's version if you intend to cite from the work. See Guidance on citing.

To link to this article DOI: http://dx.doi.org/10.1016/j.jwb.2018.07.007

Publisher: Elsevier

All outputs in CentAUR are protected by Intellectual Property Rights law, including copyright law. Copyright and IPR is retained by the creators or other copyright holders. Terms and conditions for use of this material are defined in the End User Agreement.

www.reading.ac.uk/centaur 
Central Archive at the University of Reading

Reading's research outputs online 


\title{
Boundary spanners, HRM practices, and reverse knowledge transfer: the case of Chinese cross-border acquisitions
}

\begin{abstract}
This paper investigates the role of boundary spanners in reverse knowledge transfer in EMNEs' cross-border acquisitions. Applying a micro-foundational approach and building on boundary spanning as theoretical perspective, we conducted case studies of acquisitions by Chinese companies in Germany and the UK. We find reverse knowledge transfer is a collective endeavour that relies on both the ability and motivation of individual boundary spanners as well as team-based international collaborations. We propose a conceptual framework of reverse knowledge transfer with two mechanisms-enabling and materializing. Their successful implementation depends not only on the personal characteristics of boundary spanners, but on supportive HRM practices.
\end{abstract}

Keywords: Boundary spanner, reverse knowledge transfer, micro-foundation, HRM practices, Chinese cross-border acquisitions, Europe 


\section{Introduction}

A phenomenon that, arguably, is challenging traditional MNE theories is strategic assetseeking investments by emerging market multinational enterprises (EMNEs) that aim to develop — rather than exploit — corporate resources internationally (Cui, Meyer, \& Hu, 2014; Rui \& Yip, 2008). Many EMNEs acquire advanced technologies in advanced economies with the aim to catch up with global leaders (Kumaraswamy, Mudambi, Saranga, \& Tripathy, 2012), to enhance global competitiveness, and eventually to gain an edge over competitors from advanced economies (Luo \& Tung, 2007, 2018). Therefore, cross-border acquisitions constitute a primary entry mode for EMNEs setting up operations abroad (Cui \& Aulakh, 2018; Williamson \& Raman, 2011). Yet, after an overseas acquisition, EMNEs - notably, Chinese MNEs - often prefer to adopt a 'light-touch approach' in managing their acquisition targets, giving the acquired units a high degree of autonomy (Chen, Ding, Meyer, Wang, \& Xin, 2018; Liu \& Woywode, 2013; Wang, Luo, Lu, Sun, \& Maksimov, 2014). This creates an apparent paradox: on the one hand, knowledge transfer is a major motivation of these acquisitions, yet, the post-acquisition organizational form does not seem to facilitate such knowledge transfer. This raises the question: how can knowledge be shared within a loose style integration approach as commonly adopted in Chinese cross-border acquisitions?

The transfer of knowledge between units within MNEs is a core element of the management of MNEs (Li, Zhang, \& Lyles, 2013). Traditionally, scholars have focused on knowledge flows from headquarters to subsidiaries, while recent studies also consider knowledge flows from subsidiaries to headquarters, also known as reverse knowledge transfer (Ambos, Ambos, \& Schlegelmilch, 2006; Yang, Mudambi, \& Meyer, 2008). This literature has identified a range of organizational characteristics facilitating such knowledge transfers, including socialization mechanisms (Khan, Shenkar, \& Lew, 2015b), knowledge networks (Hansen, 2002), the closeness of interactions between global and local entities (Li, Easterby-Smith, Lyles, \& Clark, 2016), the maturity of the sending unit (Rabbiosi \& Santangelo, 2013), and the absorptive capacity of the receiving unit (Minbaeva, Pedersen, Björkman, \& Fey, 2014).

However, ultimately, knowledge sharing depends on actions of specific individuals and teams at critical interfaces in the organization. These individuals are known as boundary spanners, defined as individuals who possess particular abilities and characteristics suited to cross organizational ‘boundaries' (Schotter, Mudambi, Doz, \& Gaur, 2017; Tippman, Sharkey Scott, \& Parker, 2017). Recent studies investigate boundary spanning activities in inter- 
organizational relationships, highlighting in particular their critical role in technology scouting (Monteiro \& Birkinshaw, 2017) and between foreign firms and their local partners or suppliers in emerging markets (Huang, Luo, Liu, \& Yang, 2016; Khan, Lew, \& Sinkovics, 2015a). Other studies examine boundary spanning between different units within the same MNE (Minbaeva \& Santangelo, 2018), though rarely in post-acquisition contexts (Colman \& Rouzies, 2018). Our study of boundary spanners in EMNEs' cross-border acquisitions explore a context where boundary spanning activities are particularly important for organizational objectives, but potentially subject to significant institutional obstacles.

What attributes help individuals to act as boundary spanners? The willingness of boundary spanners has been identified as an important aspect (Klueter \& Monteiro, 2017; Roberts \& Beamish, 2017), yet we lack understanding of why and how the willingness of boundary spanners influences knowledge transfers. Moreover, a prevailing assumption holds that boundary spanners are associated with a low power status (Kane \& Levina, 2017), yet this may not apply for EMNE cross-border acquisitions in advanced economies. Especially their strategic asset seeking investments are associated with strong learning motivations to gain industry experience and advanced knowledge. Thus, boundary spanners in an acquired unit potentially have a high power status due to the intended role of the acquired firm in the global MNEs (Meyer \& Xin, 2018). This suggests to reconsider the role of the status of boundary spanners in reverse knowledge transfer.

The individuals acting as boundary spanners react to stimuli in their direct organizational environment, which in turn are shaped by the organization's human resource management (HRM) practices. The critical role of HRM practices in facilitating knowledge sharing has been highlighted in studies of post-acquisition processes (Brueller, Carmeli, \& Markman, 2016; Sarala, Junni, Cooper, \& Tarba, 2016), for example, to handle potential culture clashes (Weber \& Fried, 2011), and to retain key employees (Ahammad, Tarba, Liu, \& Glaister, 2016). Yet, the development of HRM practices and of HR capability has been identified as major challenge in EMNEs' early internationalization due to their lack of internationally experienced talent (Cooke, Wu, Zhou, Zhong, \& Wang, 2018; Meyer \& Xin, 2018). Moreover, we lack understanding how HRM practices influence boundary spanners' ability and willingness to effectuate knowledge sharing. Therefore, our study aims to provide a nuanced and contextualized understanding of reverse knowledge transfer in cross-border acquisitions with two guiding research questions: (a) What mechanisms underpin reverse knowledge transfer in EMNE cross-border acquisitions while taking into account the boundary spanners' personal 
characteristics? (b) How do HRM practices help or hinder how boundary spanners affect reverse knowledge transfer?

This study contributes in several ways to our understanding of knowledge management. First, it provides an analysis of the role played by boundary spanners and HRM practices in the context of Chinese cross-border acquisitions. Specifically, we identify mechanisms enabling knowledge sharing and propose a conceptual framework for reverse knowledge transfer in cross-border acquisitions. This framework identifies enabling and materializing as two distinct roles played by boundary spanners, which are conditioned by HRM practices. Second, our study sheds light on the factors influencing boundary spanners by highlighting their motivations from a psychological perspective and their power status from an institutional perspective. Third, while boundary spanning research mainly focuses on individuals, our findings suggest that individuals do not act alone in spanning boundaries, but operate within international teams. The team dynamics significantly shape reverse knowledge transfer in the post-acquisition process. Thus, the realization of reverse knowledge transfer in EMNE crossborder acquisitions is critically dependent on the ability, power status, and willingness of individual boundary spanners, in conjunction with HRM practices that promote collaboration and social interaction in teams.

This article is structured as follows. First, we discuss the current research on boundary spanners, reverse knowledge transfer, HRM practices in EMNEs, and identify a gap resulting in absence of studies investigating reverse knowledge transfer in cross-border acquisitions. Next, we introduce the context of Chinese cross-border acquisitions and describe the qualitative research design of our study. Subsequently, we present our empirical findings drawn from German and British companies acquired by Chinese ones. We conclude by outlining the theoretical and managerial implications and by suggesting future research directions.

\section{Boundary spanners, HRM practices and (reverse) knowledge transfer: a micro- foundational perspective}

Boundary spanners are individuals who possess particular abilities and characteristics suited to bridge organizational boundaries (Levina \& Vaast, 2005). The relevant 'boundaries' have been defined either by organizational ownership from an economics perspective, or by shared identities and belongingness from a sociological perspective (Schotter et al., 2017). Boundary spanning individuals can play the role of gatekeepers in transferring information between organizations and their external environments (Tushman \& Katz, 1980). Recent studies of 
inter-organizational boundary spanning have shown how boundary spanning behaviour may benefit exchange parties' relationship quality (Huang et al., 2016) and how international joint ventures can act as boundary spanners helping local suppliers with technological knowledge transfer (Khan et al., 2015a).

Boundary spanners, however, also play an important role within MNEs, especially MNEs that are subject to internal boundaries caused by geographies, cultures or historical identities. The conditions for individuals to engage in such intra-MNE boundary-spanning activities, and their performance implications have recently (re)gained scholarly attention (Minbaeva \& Santangelo, 2018; Monteiro \& Birkinshaw, 2017; Schotter \& Beamish, 2011). Boundaryspanners identify potential individuals as senders or receivers of knowledge and facilitate processes that interactions between these individuals (Monteiro \& Birkinshaw, 2017). Thereby, they can foster cross-unit knowledge sharing and to enable creative solutions within an organization, for example by maintaining close connections with colleagues in other units (Zhao \& Anand, 2013), by facilitating collective, repeated, and iterative social interactions (Tippman et al., 2017) and by acting as higher-level intermediaries coordinating across functional and geographical boundaries by mobilizing resources and connecting different parties, (Patriotta, Castellano, \& Wright, 2013). These boundary-spanning activities can be expected to be particularly critical in cross-border acquisitions that have knowledge transfer from the acquired firm to its new parent as a core objective, as is the case in the strategic asset seeking acquisitions (Luo \& Tung, 2018; Meyer, 2015).

Individuals require not only distinct abilities, but need to be motivated to play this challenging role. For instance, Roberts and Beamish (2017) recently show that the persistent willingness of returnee executives to act as boundary spanner can enhance organizational member awareness and facilitate capacity building and commitment in adopting foreign practices in Korean financial companies. Similarly, Levina and Vaast (2005) find that an individual must be inclined to fulfil the role of boundary spanner in order to succeed in boundary-spanning activities in the IT outsourcing industry. Klueter and Monteiro (2017) highlight the importance of performance feedback on the motivation of boundary spanners in MNEs to persist in their scouting endeavours. Yet, despite the recognition of motivation in boundary spanning research, we still lack of understanding how the motivation of boundary spanners affects inter-unit knowledge sharing in MNEs (Mudambi \& Swift, 2009). 
Knowledge sharing within MNEs can follow either traditional headquarters-to-subsidiaries flows, a reverse flows, or lateral flows between overseas subsidiaries (Yang et al., 2008). Prior studies mostly investigated subsidiaries as recipients rather than as originators of knowledge (Michailova \& Mustaffa, 2012), though recent studies started to pay attention to subsidiaries as originators of knowledge flows (Monteiro, Arvidsson, \& Birkinshaw, 2008). Thus, knowledge management shifted from one-directional 'channelling' processes to the more complex higher value-added activities that help MNEs identify and make use of external sources of knowledge (Monteiro \& Birkinshaw, 2017).

Scholars have identified organization level mechanisms enabling knowledge transfer within MNEs, such as knowledge networks (Hansen, 2002), formal and informal socialization between global and local entities (Khan et al., 2015b; Li et al., 2016). In addition the structural characteristics of the organization matter, especially the maturity of the sending unit (Rabbiosi $\&$ Santangelo, 2013) and the absorptive capacity of the receiving unit (Minbaeva, Pedersen, Björkman, Fey, \& Park, 2003; Minbaeva et al., 2014). In our context, HRM practices are likely to be particularly critical as they shape the motivations of the individuals at the core of knowledge sharing activities, the boundary spanners. For example, boundary spanning activities can increase individual role overload, which may have detrimental consequences for individuals' assessed performance (Wang, Liu, \& Liu, 2018). Thus, appropriate HRM practices, such as team-based collaboration, may significantly affect boundary spanning behaviours and thereby the effectiveness of knowledge sharing.

HRM practices have been shown to be critical for knowledge transfer in acquisitions (Brueller et al., 2016; Sarala et al., 2016). For example, one recent study finds that union representativeness as boundary spanners can significantly affect post acquisition integration process by leveraging their intra- and inter-organizational pre-acquisition relationships (Colman \& Rouzies, 2018). However, we still lack understanding of how HRM practices impact on boundary spanners, who are the critical actors in knowledge sharing processes. For example, how do willingness and motivation affect reverse knowledge transfer? Adopting a micro-foundation approach (Felin, Foss, \& Ployhart, 2015), we offer some novel insights to fill this theoretical gap. Hence, our focal research questions are: (a) What mechanisms underpin reverse knowledge transfer in EMNE cross-border acquisitions while taking into account the boundary spanners' personal characteristics? (b) How do HRM practices help or hinder how boundary spanners affect reverse knowledge transfer? 


\section{EMNE cross-border acquisitions in advanced economies: an institutional perspective}

EMNEs venturing into advanced economies have recently attracted intense interest from scholars (Buckley et al., 2018; He, Khan, \& Shenkar, 2018; Luo \& Tung, 2018; Meyer \& Peng, 2016), businesses practitioners (EY, 2015), and policymakers (UNCTAD, 2016). For example, the Chinese outbound foreign direct investment (OFDI) grew rapidly. China's OFDI flows ranked fifth in 2009, third in 2012, and second in 2015, respectively, in the world. In 2015 Chinese firms' OFDI flows surpassed their counterparts of Japan, recording China as a net capital outflow country for the first time in history (UNCTAD, 2016).

The home country context plays an important role in explaining the distinct patterns and challenges faced by EMNEs (Estrin, Meyer, \& Pelletier, 2018; Hobdari, Gammeltoft, Li, \& Meyer, 2017). The home country and industry context shape in particular decisions to invest directly abroad (Alon, Leung, \& Simpson, 2015) and to engage in cross-border acquisitions (Spigarelli, Alon, \& Mucelli, 2015). In particular, acquisitions have been identified as a primary entry mode for EMNEs venturing into advanced economies (Cui \& Aulakh, 2018), especially in the case of Chinese firms (Alon, Child, Li, \& McIntyre, 2011).

However, the resource and institutional environment of the home country creates unique constraints on the international growth of EMNEs, as emerging economies normally have less munificent business environments. This includes in particular a lack of resources EMNEs can draw upon in developing their own capabilities, including for example HRM capabilities (Collings, 2014; Cooke, Saini, \& Wang, 2014; Cooke et al., 2018). At the same time, EMNEs (especially Chinese MNEs) lack internationally experienced talent with experience in crossborder boundary spanning activities (Meyer \& Xin, 2018). Thus, acquired subsidiaries of Chinese MNEs often largely rely on managers in the acquired target for critical management tasks, including knowledge management (He et al., 2018). For potential boundary spanners in such contexts, three salient aspects arise from this institutional contexts - namely (1) language competences, (2) power status, and (3) motivation.

First, language competences affect perceptions, interpretations, and interactions between business partners (Santacreu-Vasut, Shenkar, \& Shoham, 2014). For instance, language differences can influence the power dynamics in the collaborative activities of multinational teams (Tenzer \& Pudelko, 2017), and they can become a barrier to the formation of trust within 
such structures (Tenzer, Pudelko, \& Harzing, 2014). Research found that cultural and language skills constitute critical resources for boundary spanning within MNEs (Barner-Rasmussen, Ehrnrooth, Koveshnikov, \& Mäkelä, 2014). Furthermore, the nuanced aspects of languages are important in international business. For instance, using language-based gender distinctions, Santacreu-Vasut, Shenkar and Shoham (2014) find that instances in which the dominant language marked gender more intensely saw a significantly lower female participation on boards of directors and in senior management, as well as fewer female-led corporate teams. Using gaps in linguistic gender marking between home and host countries, it is found that the presence of female directors impacts cross-border M\&A activity (Bazel-Shoham, Lee, Rivera, $\&$ Shoham, 2017). Yet, the language competences of top management in China tend to be weak (compared to their peers of similar age and seniority in other countries) due to the relatively recent opening of China.

Second, the status of the individuals possessing knowledge in EMNEs cross-border acquisitions in advanced economies is different from that usually assumed in M\&A research. Studies usually assign a high power status to the HQ and a low one to the subsidiaries. Therefore, reverse knowledge transfer necessitates boundary spanners to navigate through the social identity threat arising from being associated with a lower status group (Kane \& Levina, 2017). Related research found how low-power actors in subsidiaries can gain influence in MNEs through micro-political bargaining (Bouquet \& Birkinshaw, 2008). However, in EMNE cross-border acquisitions, power status differs from this conventional conceptualization. EMNEs are strongly motivated to assess technology, knowledge, and how-how in their assetseeking overseas acquisitions (Liu, Öberg, Tarba, \& Xing, 2018). In MNEs, superior knowledge confers power (Mudambi \& Navarra, 2004); thus, a target company in an advanced economy often has a technology-based power status higher than that of its new parent company. However, existing theoretical models fail to explain how boundary spanners can facilitate reverse knowledge transfer in such a high power status context.

Third, the motivation and persistent willingness of boundary spanners is important (Klueter \& Monteiro, 2017; Roberts \& Beamish, 2017). Knowledge acquisition is a key motivation for EMNE cross-border acquisitions, yet it is not clear whether the expected knowledge sharing is equally appreciated by potential boundary spanners in the acquired organizations, especially in view of the growing anti-globalization sentiment (Liu \& Vrontis, 2017). The target company employees may fear losing their jobs due to the acquisitions, especially in the manufacturing industry (Xing, Liu, Tarba, \& Cooper, 2017). Thus, how can reverse knowledge transfer be 
effectively implemented in EMNE cross-border acquisitions while taking into account the boundary spanners' motivations?

\section{Method}

\subsection{Empirical field: Chinese acquisitions in Germany and UK}

Recent trends show a sharp increase of Chinese overseas acquisitions, with Germany becoming the top destination for Chinese investment in Europe. In 2017 Chinese companies made 247 acquisitions throughout Europe, with a total amount of USD 57.6 billion. Chinese companies made 54 transactions in Germany, making it the first place in the country ranking, followed by 44 transactions in the UK (EY, 2018). The location choice of Chinese overseas investment resonates with the country and industry-specific characteristics (Estrin et al., 2018). For instance, Chinese acquisitions in Germany mainly focus on manufacturing and machinery companies (Klossek, Linke, \& Nippa, 2012; Knoerich, 2010; Liu \& Woywode, 2011), while in the UK they mainly concentrate on the service sector, notably in the financial services, retail and consumer services (Xing et al., 2017).

Moreover, the choice of Germany and the UK as hosts allows us to develop a nuanced understanding of the impact of host country institutions because these countries represent different economic systems. The Variety of Capitalism literature (Jackson \& Deeg, 2008) identifies Germany and the UK as representatives of two distinctive models of capitalism. Germany is a co-ordinated market economy (CME), whereas UK represents liberalized market economy (LME). CMEs rely more on formal and informal regulations as well as non-market coordination between different stakeholders. In contrast, LMEs emphasize the dominant role of markets in coordinating all economic activity. One illustrative example is the role played by trade unions. In CME, trade unions are viewed as legitimate actors in the social and business sphere and in consequence it is often time-consuming and costly to lay off people. In LME, it is comparatively easy to lay off people. This difference between CME and LME can have substantive impact on the management of post-acquisition integration or restructuring processes. For example, US companies experience considerable challenges when laying off employees in acquired companies in Germany (Capron \& Guillén, 2009). By exploring acquisitions in these two distinct countries, we aim to ensure the validity of our findings across geographical locations and industries.

\subsection{Qualitative research method}


The exploratory nature of our research questions suggests that a qualitative research approach is appropriate. We use multiple case studies with the purpose of extending the existing theory and generating new theoretical insights (Birkinshaw, Brannen, \& Tung, 2011; Eisenhardt, 1989; Eisenhardt \& Graebner, 2007), specifically to refine our understanding of key constructs and their antecedents, and to discover relationships between such constructs. Birkinshaw, Brannen and Tung (2011) are encouraging qualitative research specifically to capture the nuances and complexity of an emerging field and described as particularly useful in theorizing endeavours in international management and business studies. Scholars have shown increasing interest in applying qualitative research methods to investigate knowledge transfer in international business (Khan et al., 2015a; Li et al., 2016; Monteiro \& Birkinshaw, 2017). Recent applications on Chinese MNEs include phenomena such as post-acquisition integration (Liu \& Woywode, 2013), subsidiary capability upgrading (He et al., 2018), and global competitiveness enhancement (Spigarelli et al., 2015).

\subsection{Sample and data}

This study is part of a large research project on Chinese overseas investment. We used several sources and a step-wise process to identify acquisitions by Chinese companies in Germany and the UK. First, we checked with the SDC Platinum from Thomson Financials, which is widely used by M\&A scholars (Sun, Peng, Ren, \& Yan, 2012). Second, we searched news, press releases, websites, and company announcements to gather the relevant information. Third, we leveraged our professional and personal networks to seek out interview informants in the identified cases.

For this study, we chose four cases in the German manufacturing industry and the UK services industry (Table 1). These industries and locations represent a major share of Chinese acquisitions in Europe over the past decade (EY, 2018). In all four acquisition cases, reverse knowledge transfer featured prominently among the stated objectives. Our selection of cases was guided by our research framework developed from the literature on boundary spanning and knowledge transfer. To attain high levels of internal validity, we employed theoretical sampling. This approach helps to "maximise opportunities to discover variations among concepts and to densify categories in terms of their properties and dimensions" (Strauss \& Corbin, 1998: 201). In other words, "theoretical sampling simply means that cases are selected because they are particularly suitable for illuminating and extending relationships and logic among constructs" (Eisenhardt \& Graebner, 2007: 27). In this study, we chose acquisitions 
exhibiting variations in achieved knowledge transfer as evidenced in our preliminary investigations. In other words, some acquisition scored well on reverse knowledge transfer and some not.

---- Insert Table 1 about here----

Overall, we conducted semi-structured in-depth interviews with 22 managers at both senior and middle levels and we collected information from the viewpoints of both the acquiring and target companies. These five to seven interviews per case of managers at multiple levels of seniority were carried out either face-to-face or by phone and lasted for an average of 1.5 hours (see Table 2). They were conducted in German, English or Chinese as per the preference of the interviewee. Following a theoretical sampling approach, we stopped adding interviewees when further interviews ceased to generate additional significant information. This balanced approach to data collection enabled us to obtain multiple and complementary perspectives on the role played by boundary spanners in reverse knowledge transfer. Thus, it facilitated the enhancement of construct validity during the data collection phase (Gibbert, Ruigrok, \& Wicki, 2008).

---- Insert Table 2 about here----

To further enrich our data, we conducted supplementary interviews with managers and consultants involved in Chinese outbound FDI activities, including greenfield investment and joint venture projects. In so doing, we aimed to obtain a comprehensive and granular understanding of the acquisitions cases embedded in the broader context of Chinese overseas investment. These other cases provided a useful background for this study. In addition, we triangulated data with public available information such as annual reports and news reports in Chinese, German and Chinese media. Examining the same phenomenon from different angles by using different data collection strategies and data sources enhanced the construct validity of our case studies (Gibbert et al., 2008).

The interviews followed an open ended interview protocol that allowed interviewees to describe their working experience throughout the acquisition process. These in-depth interviews thus covered three phases of the process-namely, pre- acquisition, acquisition negotiation and transaction, and post-acquisition integration (Table 3), taking advantage of the fact that most interviewees have been involved in either of the companies already before the acquisition took place. This rich database enabled us to generalize the findings at the theoretical 
level. Specifically, we applied comparative case analysis to capture the complexity and richness of the reverse knowledge transfer phenomenon and to search for patterns across our cases. We followed the suggestion of pattern-matching to enhance the internal validity of case studies (Eisenhardt \& Graebner, 2007; Gibbert et al., 2008).

\section{---- Insert Table 3 about here----}

In analysing our data, we took a grounded theory approach (Gioia, Corley, \& Hamilton, 2013; Glaser \& Strauss, 1967) by following the established techniques and procedures with three steps. We used NVivo 11, a qualitative research software that facilitates the analysis of qualitative data. In the first step of the analysis, interview transcripts, entered as text files in NVivo, were coded on the basis of "in vivo" words. These comprised phrases, terms, or descriptions offered by interviewees around the boundary spanning behaviour, HRM practices and knowledge transfer. During this step, NVivo facilitated the process of organizing the codes that emerged from the data. Then, we looked for codes across interviews that could be collapsed into higher-level nodes, namely first-order categories. During the analysis, we always tried to retain the language used by informants. The higher-level, or "tree nodes," were then refined through triangulation of sources (interviews, participant observations, etc.) to produce a set of first-order categories. Examples of first-order categories include "light-touch integration," "market opportunity," and "team-based project."

The second step of our analysis involved looking for links among first-order categories so that we could collapse these into theoretical-oriented second-order themes. As recommended by Eisenhardt (1989), this process was recursive rather than linear; we moved iteratively between the first-order categories and the emerging patterns in our data until adequate conceptual themes emerged. For example, categories containing instances in which informants talked about the benefits of Chinese acquirer's light-touch integration or market opportunity in China via acquisition were collapsed into a theme labelled "willingness to collaborate."

The third step of the analysis involved organizing the second-order themes into the overarching dimensions that eventually underpinned our theorizing efforts. The emergent data structure with first-order and second-order coding, and aggregated theoretical dimensions with selective empirical evidence is illustrated in Table 4. Two dimensions emerged strongly here. The first theme was the mechanism of "enabling" from the target boundary spanners' perspective encouraging boundary spanners to take initiatives and patterns of psychological underpinnings; the second dimension emphasized the "materializing" from the perspective of both target and 
acquirer and patterns of behaviour underlying reverse knowledge transfer. We elucidate the data analysis process by displaying the data structure in Figure 1.

---- Insert Figure 1 about here----

---- Insert Table 4 about here----

\section{Results}

In our four case companies, boundary spanners included both senior and middle managers who operated at an interface between acquirer and target, and were involved in collaborative activities either at the organization or project levels. Our analysis identified three enabling conditions for reverse knowledge transfer-namely: (1) the abilities of the target's boundary spanners, (2) the target's high power status, and (3) the target's willingness to collaborate. In addition, collaborative HRM practices and social interaction are two salient building blocks in implementing the reverse transfer of knowledge from target to acquirer.

\subsection{The abilities of the target's boundary spanners}

Our data analysis suggests that the abilities of the target's boundary spanners consist of two aspects of their personal profiles as important factors that enable or hinder reverse knowledge transfer: (1) cultural competence and (2) language skills. Individuals devoid of these two sets of skills found it difficult to establish the necessary interfaces for reverse knowledge transfer.

Cultural competence can play an important role in enabling boundary spanning activities in Chinese overseas acquisitions. The familiarity of the target's Top Management Team (TMT) with Chinese culture in particular-and with Eastern cultures in general - can cultivate a positive attitude towards the Chinese acquirer. ${ }^{1}$ This, in turn, may enable reverse knowledge transfer. The managing director in Case A, a German national with professional experience in China, explained,

"The reason that I'm running the European operation of this company is because I have spent quite a long time in China assisting the German governmental agency to manage technology transfer projects. I got contacted when I registered with VDMA Beijing, Verband Deutscher Maschinen- und Anlagenbauer [Association of German Machinery and Plant Engineers]. The German firm went bankrupt when the Chinese acquired, before I took the helm to steer the ship. I think you have to understand the culture before working with the Chinese."

\footnotetext{
${ }^{1}$ In the four case companies, this observation was corroborated by conversations held in Shanghai's expat community, during which several individuals reported that they had been targeted by headhunters aiming to fill local leadership roles in the Chinese MNEs' operations in such individuals' home countries.
} 
When the TMTs had been exposed to multi-cultural contexts through professional and educational experiences, the notion of bi-culturalism emerged from our case analysis. This can be observed from Cases A and D. The Chinese Chairman of Case D had worked in the US and Canada before serving as Chairman after the Chinese acquisition in the UK. By contrast, the TMTs in Cases B and C tended to remain mono-cultural. A lack of familiarity with Chinese culture sometimes caused misunderstandings of the Chinese companies' behaviours and expectations. The international partnership manager of the Case $\mathrm{C}$ target shared:

"The hardest thing we find is the lack of consistency in comments or decisions. What I mean by that is that the Chinese multiple departments do not speak to each other. So you get different instructions on the same subject from different departments. Those instructions also change over time. This means that, when you have put in lots of time, energy, and efforts, it is a waste to change instructions."

Knowledge transfer between subsidiaries and HQ needs to attend to and leverage the power of local knowledge (Li et al., 2016); however, boundary spanners with local knowledge also need to understand the cultural differences to take action. Furthermore, the economic development in China and the momentum of Chinese overseas acquisitions are giving Chinese managers the confidence to venture abroad, and provide the financial resources to make substantial acquisitions. However, Chinese companies need time to build their capabilities and cultivate their language skills in dealing with overseas targets.

Furthermore, the boundary spanners' language skills and ability to communicate with acquirers can play a critical role, especially considering the important bearing of culture on the implied meanings of words and expressions in different languages. One senior German project manager in Case A shared:

“When the Chinese colleagues say 'yes, yes', it does not mean 'yes' in terms of decision making. Rather, it means I understand or I accept this. But it does not mean that I agree with you on the opinion. But these are precisely these topics, since the Germans still have to learn a bit in the sense of cultural understanding. This is about the experiences not from text books, from a practical situation, how can I evaluate what just happened?"

Hence, boundary spanners can play a crucial role in facilitating the connection between acquirer and target and in bridging cultural differences. Our analysis lends further support to the argument in support of cultural and linguistic skills as boundary spanning resources within MNEs (Barner-Rasmussen et al., 2014) in the context of Chinese overseas acquisitions.

\subsection{The target's high power status}

Our analysis reveals that a target having a higher power status can foster reverse knowledge transfer. Chinese companies have a strong learning motivation when conducting asset-seeking overseas acquisitions (Liu \& Woywode, 2011). Industry-specific experience and advanced product and market knowledge grant the target's boundary spanners a higher power status that enables reverse knowledge transfer. 
The British CFO from Case C explained:

"The reason why they bought us was to take our concept, and open it in China. What we do know is how to actually operate the business due to our vast industry experience, so they should be bringing together their knowledge of China and our knowledge of the business. Because that [way] you will have two complementary sides of the equation. The people who were involved in that transfer of knowledge between China and ourselves were those involved in design and product buying."

As this narrative illustrates, Chinese companies seek to acquire industry-specific experience and knowledge on operating on a global scale. Advanced knowledge is associated with a higher power status, which makes Chinese companies listen to their overseas targets' suggestions and input. Thus, a higher power status paves the way for the target's boundary spanners to initiate and implement reverse knowledge transfer practices.

In a similar vein, we observed the transfer of product knowledge in manufacturing companies as a result of the target's higher power status. The Director of Strategy \& Business Development of Case B-who had Chinese ancestry but had been born in Germany—-shared:

"The Chinese acquirer mostly produces construction engines for heavy duty truck. So, they produce high power engines for the construction industry. The Chinese acquirer is very interested in the hydraulics business. Therefore, they try to learn from our product development department, especially focussing on engines."

The Chinese acquirer's motivation to gain product knowledge from the overseas target contributes to the social construction of a situation of power asymmetry between the two parties. Due to their possession of advanced knowledge, industry know-how, and industry-specific experience, overseas targets in advanced economies tend to be associated with a higher power status (Mudambi \& Navarra, 2004).

\subsection{The target's willingness to collaborate}

Contrary to conventional wisdom, which postulates that knowledge transfer needs to occur within a tight post-acquisition integration, our cases suggest the possibility of reverse knowledge transfer being initiated by boundary spanners. Specifically, the willingness of the target's boundary spanners to collaborate with the acquirer is enabled by (1) the light-touch integration, and (2) the market opportunities provided to the target.

With the light-touch integration approach, acquirer grants high autonomy to target after the acquisition (Liu \& Woywode, 2013; Wang et al., 2014). The degree of autonomy granted establishes the playground in which new initiatives may take place (Raisch \& Tushman, 2016). Our analysis found that the granting of a high degree of autonomy in the post-merger acquisition phase gives the target TMT the freedom to operate the overseas business unit. Due to the benefits afforded by 'light-touch integration', the target can not only make operationallevel decisions, but also investment ones. The target can benefit from gaining easy access to the resources provided by the acquirer — such as raw materials and financial capital—which 
help the target TMT to continue business operations. The target's sales director in Case A revealed:

"The raw materials from our Chinese mother company are cheaper compared to the available market prices. Thus, we are happy to explore the potential and work with our Chinese mother company."

Thus, the potential benefit of collaborating with the Chinese acquirer triggers the target's willingness to do so. Furthermore, the flexible allocation of resources within the target associated with the granted degree of autonomy may generate opportunities for the development of new knowledge that can be eventually transferred from the target to the acquirer. The German marketing manager of Case B explained:

"As for the engine business there, it was just in the beginning. They [the Chinese acquirer] invested heavily in $R \& D$ and tried to develop advanced technology that is applicable for construction industry. Now they [the German unit] have a chance to become a smaller Bosch Rexroth, they will have the money and resources now to do that. With the previous owner, it was not possible."

In addition, the market opportunities provided by the Chinese acquirer can strengthen the boundary spanners' willingness to collaborate. Vice president in Case D shared:

"As we know, the Chinese financial market is still highly regulated. Foreign financial institutions cannot easily get there. You need permission from the government and regulators. After the acquisition, we formed strong bond with one of the largest Chinese state-owned commercial banks. This may open up the significant market opportunity for us."

Hence, knowledge transfer requires boundary spanner bottom-up initiatives aimed at mobilizing the flow of knowledge from the subsidiary (target) to the HQ (acquirer) (Tippmann, Scott, \& Mangematin, 2014). The light-touch integration approach granting high autonomy to the target and the market opportunities presented by the Chinese market enable boundary spanners to take such initiatives.

\subsection{Collaborative HRM practices between acquirer and target}

Our analysis suggests that the activities of boundary spanners need to be aligned with appropriate HRM practices in reverse knowledge transfer. We identified two HRM practices that can contribute to the materialisation of reverse knowledge transfer: (1) team-based collaboration and (2) training and dedicated workshops.

Team-based collaboration plays a crucial role in reverse knowledge transfer. The process of knowledge transfer unfolds and knowledge is transferred through a teamwork platform. The Director of Corporate Strategy from Case B shared: 
"There are five projects defined after the closing to realize the synergy between us and the Chinese company. For these projects, we don't have any external integration manager, and I was heading those projects. We had five in the beginning, then these were expanded into seven projects. We have seven project teams, usually made up of Chinese and German led sub-teams. These project teams can share practices from both sub-teams, solve specific Chinese problems to foster knowledge exchange. It is much better than just buying the existing IP [intellectual property]. Because the IP might not work for the Chinese firm."

Reverse knowledge transfer may be effected by a team, rather than by an individual boundary spanner. We observed teams, consisting of both Chinese and German employees, that were capable of identifying knowledge gaps and of transferring know-how between target and acquirer. Collaborative efforts are conducive to finding solutions suited to address the particular challenges faced by Chinese companies. Furthermore, team-based collaboration may provide opportunities to come up with new products and solutions. The CEO of Case B mentioned:

"Our collaborative projects with German and Chinese employees on board can help both sides to understand the opportunity. We encourage joint work to develop new products that address the Chinese market demand. This comes from team-based project collaboration"

Importantly, despite a tendency towards a lack of formal integration by Chinese companies in their overseas acquisitions (Liu \& Woywode, 2013), reverse knowledge transfer can still occur by virtue of team-based collaboration. This requires knowledge transfer initiatives championed by boundary spanners, and the frequent interaction of employees from both sides through teambased collaboration.

Another important HRM practice involves offering dedicated workshops and training. Workshops provide a platform that enables employees to mingle with and learn from each other. The Chinese chairman of Case D explained:

"We organize workshops for our employees, so they can exchange knowledge between here [the UK] and China. The regulatory frameworks in the financial industry are country-specific. The regulations and practices in China are often not applicable here in the UK. Therefore, we need to learn from local people. This acquisition speeded up our global expansion, as we want to offer investment banking services. Workshops helped us to share knowledge and to learn from local practices as well."

Workshops have been identified as a useful mechanism for coordinating knowledge exchange when global managers behave as trans-regional high-level intermediaries in MNEs (Patriotta et al., 2013). Case D illustrates a particular salient dimension related to institutional differences. Hence, institutional contexts need to be incorporated into the content of dedicated workshops and training. Besides functional workshops, which focus on technical knowledge and knowhow, soft workshops that cover cross-cultural differences and language skills in particular are also important. 
The German project management director of Case B emphasized such importance:

"The project with WF [a city in China] works well. But we have language issues and culture issues. The management does not speak English. I cannot be the translator all the time. They hired a translator in the end. I think that cross-cultural workshops are especially important."

Also, training and workshops that enhance employee language competence are identified as important HRM practices in assisting boundary spanners in the reverse knowledge transfer process.

\subsection{Social interaction of employees in acquirer and target}

Another important building block for the implementation of reverse knowledge transfer is the language competence of both acquirer and target employees. Our analysis suggests that social interaction necessitates (1) mastering the language skills and (2) using language to bridge cultural differences.

English language fluency can affect employee commitment to corporate globalization efforts (Yamao \& Sekiguchi, 2015), and can be particularly salient in influencing employee reactions towards cross-border M\&As (Kroon, Cornelissen, \& Vaara, 2015). However, the senior managers of Chinese companies appear not to be prepared in terms of their English language proficiency. This resonates with the situational context in China, in which the senior managers of Chinese companies build their professional careers primarily using the Chinese language. The senior managers' lack of mastery of English language skills and the lack of experience of those younger managers who are fluent in English can hinder the target TMT in holding effective conversations with the Chinese acquirer.

The vice president from the UK company in Case C told,

"I still don't know how to have a conversation with China. But the English speakers tend to be very young and inexperienced. So our primary contacts tend to be with very young and very inexperienced people. They will pass on messages from more senior people. But this means that there is no dialogue."

Due to the vast amount of tacit knowledge linked to language competence (Kroon et al., 2015), besides proficiency in language skills, individuals in interface position need to be able to bridge cultural differences through effective communication. When, for instance, a Chinese company bought a German one, both sides needed to use English as their working language. This can result in additional challenges and language barriers compared to the case of Chinese acquisitions in the UK. This indicates the vulnerability of language competences. The HR manager of Case A shared:

"In the end, language also reflects culture very strongly. Without a cultural understanding of how to run decision-making processes in China, you cannot understand or classify certain decision-making processes or measures. And, if you cannot classify them, then discord or blockages can arise. So, from this perspective, I 
think it is for both sides. You see, our colleague Karen from China is working here after studying in Germany, so we have a case of Chinese learning the German language. But I think that the Germans will certainly have to learn a little Chinese to embrace the cultural differences. Language training is of particular relevance here."

As this narrative illustrates, bi-lingual employees in interface position may facilitate both sides in engaging with collaborative activities by communicating effectively with both acquirer and target. Therefore, the ability of employees to bridge cultural differences by using language constitutes a key language competence.

One type of boundary spanners is represented by those employees who are involved with both sides, often benefiting from employee transfers and visits to foster social interaction. Case B's Chinese-born project manager, who was based in Germany, explained:

"So, in terms of know-how transfer, we regularly send people from Germany, who then undertake tasks like training service teams, training the production in China. We also translate assembly instructions into Chinese. We have people in China-currently, German employees from the areas of production and assembly - who are also actively involved in transferring know-how; i.e., in learning by doing.",

Boundary spanners need to possess the abilities and motivation to translate the target's common knowledge to what is uncommon knowledge for the acquirer (Nag \& Gioia, 2012). Case B illuminates how the German employees help their Chinese counterparts to understand their know-how by fostering social interaction through employee transfers and visits. Thus, social interaction can facilitate the implementation of reverse knowledge transfer.

\subsection{Framework development}

Our cases analysis offers a basis to propose causal relationships between the identified constructs, and to interpret our findings to the theoretical level. Figure 2 thus presents a conceptual framework synthesizing our insights on reverse knowledge transfer, boundary spanners, and HRM practices. The framework elucidates mechanisms that underpin reverse knowledge transfer from a target to an acquirer in the context of EMNE cross-border acquisitions in advanced economies. The institutional differences between acquirers from emerging economies and targets in advanced ones provide the institutional background against which knowledge transfer may occur. Industry characteristics and industry-profile complementarity relate to the focus of the knowledge being sought after for transfer. Our empirical findings in Germany and the UK illustrate this difference. Advanced manufacturing companies and engineering knowledge represent the focal area for Chinese companies in Germany to learn and transfer, whereas service industry know-how and marketing competence are the focus to transfer for Chinese companies in the UK.

---- Insert Figure 2 about here----

Target boundary spanners having the ability associated with higher power status, and possessing the willingness to collaborate with acquirer can enable reverse knowledge transfer. 
Cultural competence and language skills prepare the target boundary spanners to interact with the acquirer. Industry-specific experience and advanced knowledge bestow a higher power status upon the target that is associated with the ability and sensitivity to spot the knowledge gap between target and acquirer. The light-touch integration approach and market opportunities motivates target employees to take initiatives in reverse knowledge transfer. Besides the ability and power status of boundary spanners, the target's willingness to collaborate is critical to enable reverse knowledge transfer.

Furthermore, the appropriate collaborative HRM practices need to be aligned with the role played by boundary spanners so as to materialize reverse knowledge transfer. Two HRM practices are of particular importance in this process: (1) team-based collaboration and (2) training and workshops. Reverse knowledge transfer cannot occur in a vacuum, without any supporting HRM practices. Team-based international collaboration between target and acquirer is the vehicle that drives knowledge flow. Specifically, tacit knowledge-devoid of explicit codes - may be transferred through team work and routines. Forming an effective team consisting of both target and acquirer members is a challenging yet beneficial endeavour. Furthermore, employee training and dedicated workshops are conducive to transmitting and materialising tacit knowledge. Social interaction plays a critical role in materialising reverse knowledge transfer (Brannen, Piekkari, \& Tietze, 2014; Tenzer et al., 2014). During social interaction, without competent language skills and the ability to bridge cultural differences through effective communication, hidden meanings of intended knowledge can be mistakenly interpreted and perceived in multinational teams (Tenzer \& Pudelko, 2017). This may result in 'lost in translation' scenarios (Klitmøller \& Lauring, 2013). Therefore, social interaction constitutes as one key building block in lubricating reverse knowledge transfer through collaborative HRM practices. In summary, the role played by boundary spanners needs to be aligned with the appropriate HRM practices underpinning the two distinctive mechanisms for reverse knowledge transfer in EMNE overseas acquisitions in advanced economies.

\section{Discussion and implications}

\subsection{Implications for theoretical development}

By explicating the role played by boundary spanners and HRM practices, our study may significantly extend the understanding of reverse knowledge transfer in emerging market companies' overseas acquisitions. First, we contribute to boundary spanning theory by emphasizing the importance of boundary spanner motivation from a psychological microfoundational perspective. This involves not only the target boundary spanners' abilities, but also their willingness to collaborate with the acquirer to enable reverse knowledge transfer. Our findings lend support to a recent study that theorised boundary spanning as being a combination of ability, persistent willingness, and opportunity (Roberts \& Beamish, 2017). Such a micro-foundational perspective on motivation — stemming from the acquirer's adoption of light-touch integration (Liu \& Woywode, 2013) and market opportunities - helps to gain a nuanced understanding of the boundary spanners' willingness to initiate and contribute to reverse knowledge transfer. 
The paper contributes to the literature on reverse knowledge transfer both by highlighting the alignment of boundary spanners and HRM practices, and by articulating the underlying mechanisms that operate between sender (target) and receiver (acquirer) in the context of crossborder acquisitions. Our findings show two mechanisms that facilitate reverse knowledge transfer from target to acquirer-namely, enabling and materializing-which are closely linked to the roles played by boundary spanners and HRM practices. To advance the understanding of boundary spanners in the context of knowledge transfer, our finding lends support to the importance of target' ability affecting boundary spanning behaviour. Furthermore, we reveal the post-acquisition conditions, elucidated by the combination of "light-touch integration" approach and the market opportunity, motivate boundary spanners to take the initiative from the psychological perspective. This finding lends further support to the existing studies indicating the motivation to transfer knowledge is conducive to the positive outcome of knowledge transfer (Minbaeva et al., 2003). Unlike previous research focusing knowledge transfer in MNEs contexts (Minbaeva et al., 2014), we argue that the role of boundary spanners in Chinese cross-border acquisitions should be viewed from the perspective of the wider context in which these boundary spanners operate their boundary spanning activities. Thus, our findings extend the discussions of knowledge transfer in the context of EMNEs venturing into advanced economies. Furthermore, our study joins the recent research to study the organizational-level role of boundary spanners in the transfer of global knowledge (Khan et al., 2015a). Our results may further advance the role of boundary spanners by examining the organizational form of collaborative partnership, such as M\&A. Furthermore, our research attempts to open "the black box" of reverse knowledge transfer by looking at the combination of boundary spanners and HRM practices, something that has been neglected by the extant research on boundary spanners (Johnson \& Duxbury, 2010; Schotter et al., 2017).

Second, building upon the institutional perspective, our study joins the conversation on the role played by subsidiaries in knowledge transfer (Michailova \& Mustaffa, 2012), especially in regard to knowledge flows and to the role played by the subsidiary managers' selling efforts (Monteiro, 2015). Importantly, the institutional context of EMNE cross-border acquisitions in advanced economies challenges the assumption that boundary spanners from subsidiaries hold a lower power status (Kane \& Levina, 2017). Our results offer a contextualized understanding of boundary spanners holding a higher power status and how such status may enable reverse knowledge transfer. Although acquiring companies from emerging economies are strongly motivated to learn from their targets, reverse knowledge transfer from cross-border acquisitions is influenced by subsidiary level competencies and capabilities (Nair, Demirbag, \& Mellahi, 2015). Our findings echo such a perspective by demonstrating how, in our case study of Chinese cross-border acquisitions, boundary spanners and HRM practices matter in addressing reverse knowledge transfer. Specifically, our findings highlight the importance of collaborative team-based HRM practices and social interaction in materializing reverse knowledge transfer. Therefore, our research is among the first to identify the role played by boundary spanners in alignment with HRM practices in reverse knowledge transfer in the context of EMNEs crossborder acquisitions. 
Relatedly, recent research has begun to emphasize the importance of micro-foundations in organization and management theory (Felin et al., 2015). Our study extends this line of reasoning by offering empirical evidence and a contextualized understanding of reverse knowledge transfer by examining HRM practices and the role played by boundary spanners in the context of Chinese cross-border acquisitions. By doing so, we extend the previous work on reverse knowledge transfer and suggest boundary spanners and HRM practices as important micro-foundations upon which future researchers can extend the body of knowledge in the context of collaborative partnerships (Liu, Sarala, Xing, \& Cooper, 2017). According to one recent review, global staffing continues to be important, yet becoming more nuanced with alternative forms (Collings \& Isichei, 2018). Our study reveals the importance of boundary spanners in enabling - and of HRM practices in materializing - reverse knowledge transfer, and supports the applicability of micro-foundational thinking beyond the organizational level and in inter-organizational relationships.

Third, our findings contribute to the extant M\&A literature, particularly in relation to postacquisition integration approaches (Haspeslagh \& Jemison, 1991). Given the peculiar characteristics of the Chinese companies' 'light-touch integration' approach to cross-border acquisitions (Liu \& Woywode, 2013) - which is similar but distinct from the symbiosis category of acquisitions - this paper provides additional insights into this literature stream from the perspective of reverse knowledge transfer. Previous research found that 'light-touch integration' is conducive to the development of service capabilities in the Chinese companies' pursuit of servitization strategies through acquisitions (Xing et al., 2017). Furthermore, by leveraging the value of foreign brands, 'light-touch integration' affects the dynamics of brand management strategies in Chinese cross-border acquisitions (Liu et al., 2018). Unlike the recent research highlighting the role of union representatives as boundary spanners to facilitate postacquisition integration (Colman \& Rouzies, 2018), our findings highlight the importance of HRM practices, such as team-based collaboration, and training and workshops for reverse knowledge transfer. Our research lends support to the view that developing HRM practices and building HR capability is critical for EMNEs' globalization endeavours (Cooke et al., 2018) by indicating the mutual benefits stemming from the team-based collaboration between target and acquirer. The existing literature on talent management ignores the international collaborative dimension in the context of EMNE (Cooke et al., 2014; Meyer \& Xin, 2018). In this article, we argue that international collaboration can be important in the moving of knowledge from target to acquirer by forming team-based collaborative projects. In addition, the role of language competence played in EMNEs' cross-border acquisitions is much broader than previously discussed, including the social interaction of employees between target and acquirer and the cross-cultural mutual understanding. Thus, the findings of this study represent an important advancement in our understanding of how knowledge is reversely transferred in the form of collaborative partnership, especially by EMNEs' cross-border acquisitions. Combining both micro-foundational perspective and institutional-based view, this study suggests an integrative way of studying the role of boundary spanners and HRM practices that contributes to the ongoing debates on knowledge transfer in MNEs (Minbaeva et al., 2014; Mudambi \& Navarra, 2004). 
The alignment of boundary spanners and HRM practices offers the possibility to achieve reverse knowledge transfer in 'light-touch integration' contexts. By juxtaposing the institutional and micro-foundational perspectives, our findings shed revealing light on the reverse knowledge transfer in the context of EMNE cross-border acquisitions in advanced economies. Our findings add to the understanding of the theoretical foundation of emerging economy business research, especially to the 'institution matters' conversation (Meyer \& Peng, 2016). In so doing, our study brings contextual variables into the reverse knowledge transfer literature by illustrating the influence of institutional contexts in Chinese cross-border acquisitions and their implications on reverse knowledge transfer.

\subsection{Managerial implications}

In the context of companies from emerging economies venturing into advanced ones through cross-border acquisitions, this study offers several implications to managers in both environments. In traditional HQ-to-subsidiary knowledge transfer, the HQ can instruct the subsidiary to acquire certain shared knowledge; conversely, in reverse knowledge sharing when control and knowledge are separated between acquirer and target, the HQ may not have an understanding of the subsidiary's advanced technologies, and therefore of their potential applications in the aftermath of their transfer. This makes reverse knowledge transfer, especially in MNEs pursuing a fast catch-up strategy, a daunting managerial challenge. Our findings suggest both target and acquirer should recognize and pay close attention to boundary spanners and to the role they play in reverse knowledge transfer. Boundary spanners, their abilities, competences, and willingness to undertake activities can strongly affect reverse knowledge transfer. A nuanced understanding of boundary spanners and HRM practices may facilitate adequate responses by the involved actors. Various institutional contexts and situations provide multiple opportunities to a wide spectrum of stakeholders. When boundary spanners identify and champion initiatives, team-based collaborations are essential in materializing reverse knowledge transfer. Knowledge can be transferred to address the pertinent issues faced by acquirers only by operating in collaborative team contexts.

Furthermore, light-touch integration and the autonomy granted to the target TMT can offer the opportunity to create new products and find novel solutions. This requires the target TMT's ability to understand and interpret cultural differences, so as to appropriately manage acquirers. Admittedly, language competence is especially important for reverse knowledge transfer; however, the cultivation of language skills and cultural sensitivity takes time and patience. We suggest that overseas target companies understand the Chinese organizational situation and institutional context while interacting with Chinese companies. Importantly, overseas targets might find themselves better off in dealing with Chinese investors by being aware of their developmental nature and of their historical and cultural contexts, and of the subsequent implications of these aspects on their intentions and competence in the pursuit of reverse knowledge transfer.

With regard to HRM practices, we suggest that these need to be aligned with the role played by boundary spanners in order to facilitate reverse knowledge transfer. In particular, dedicated training and workshops are necessary to provide both technical and soft skills. Building up the 
cultural competences of both managers and employees is especially important for reverse knowledge transfer. Employee transfers and visits can also contribute by enabling the creation of a team-based collaboration atmosphere. HRM managers can recruit local talent with language skills and cultural competence for both senior and middle-level interface positions. Reverse knowledge transfer can be affected by talent management strategies (Collings, 2014; Tung, 2016), especially those that ascribe value to the role of expatriates and returnees in emerging economy multinationals (Meyer \& Xin, 2018). We believe that this understanding can help acquiring companies to deal more effectively with global challenges and exploit the opportunities that arise out of venturing from emerging to advanced economies (Liu \& Vrontis, 2017).

\subsection{Limitations and suggestions for future research}

By unpacking the key aspects of boundary spanners and HRM practices, this paper represents an early attempt to address the question of how boundary spanners affect reverse knowledge transfer. Although our conceptualization is supported by case studies of Chinese cross-border acquisitions in Germany and the UK, we view our findings as tentative and suggest that future research efforts are made to validate our conceptualization by using a quantitative approach to capture reverse knowledge transfer. We acknowledge that there are differences between Chinese outbound foreign direct investment directed towards advanced economies and less developed countries. For instance, Chinese companies may prefer to choose greenfield investment as their entry mode in African countries (Xing, Liu, Tarba, \& Cooper, 2016). In this regard, admittedly, this study focusses on Chinese cross-border acquisitions in advanced economies. In addition, future research can also compare the roles boundary spanners and HRM practices play in emerging and in advanced economies, so as to attain an enhanced understanding of comparative international management (Luo, Sun, \& Wang, 2011).

Another potentially fruitful research stream relates to the role played by strategic agility in M\&As and its implications on reverse knowledge transfer (Junni, Sarala, Tarba, \& Weber, 2015). Our research identifies two mechanisms of reverse knowledge transfer by highlighting the role played by boundary spanners and HRM practices. Building upon the strategic agility framework (Weber \& Tarba, 2014), we encourage future research to examine the influence of leadership (Doz \& Kosonen, 2010), flexibility, and agility in the context of emerging economies. Given the unique Chinese leadership style (Xing \& Liu, 2015, 2016) and the influence of corporate language on strategic agility (Brannen \& Doz, 2012), we suggest that future research continue along this line of scholarly inquiry by viewing reverse knowledge transfer as a process, so as to gain a more comprehensive understanding of its microfoundations and its influence on reverse knowledge transfer in EMNE cross-border acquisitions.

\section{Conclusion}

This study investigates the role of boundary spanners and HRM practices in reverse knowledge transfer (from target to acquirer) in the context of Chinese cross-border acquisitions in Europe. 
We identified two mechanisms through which reverse knowledge transfer can occur-namely enabling and materializing. Our study emphasizes that the role of boundary spanners in reverse knowledge transfer should be understood in conjunction with supporting HRM practices in a nuanced manner and from a micro-foundational perspective. We hope that this study will inspire scholars to further investigate this line of inquiry. In particular, our research offers an initial attempt to elucidate the complexity of the interplay between boundary spanners and HRM practices and serves as a departure point for further theoretical refinement and empirical validation. In a nutshell, reverse knowledge transfer can be realized through team-based collaboration in conjunction with boundary spanning efforts aimed at compensating for the lack of formal integration management in Chinese cross-border acquisitions. 


\section{References}

Ahammad, M. F., Tarba, S. Y., Liu, Y., \& Glaister, K. W. 2016. Knowledge transfer and cross-border acquisition performance: The impact of cultural distance and employee retention.

International Business Review, 25(1): 66-75.

Alon, I., Child, J., Li, S., \& McIntyre, J. R. 2011. Globalization of Chinese firms: Theoretical universalism or particularism. Management and Organization Review, 7(2): 191-200.

Alon, I., Leung, G. C. K., \& Simpson, T. J. 2015. Outward foreign direct investment by Chinese national oil companies. Journal of East-West Business, 21(4): 292-312.

Ambos, T. C., Ambos, B., \& Schlegelmilch, B. B. 2006. Learning from foreign subsidiaries: An empirical investigation of headquarters' benefit from reverse knowledge transfers.

International Business Review, 15: 294-312.

Barner-Rasmussen, W., Ehrnrooth, M., Koveshnikov, A., \& Mäkelä, K. 2014. Cultural and language skills as resources for boundary spanning within the MNC. Journal of International Business Studies, 45(7): 886-905.

Bazel-Shoham, O., Lee, S. M., Rivera, M. J., \& Shoham, A. 2017. Impact of the female board members and gaps in linguistic gender marking on cross-border M\&A. Journal of World Business, Available online 22 November 2017.

Birkinshaw, J., Brannen, M. Y., \& Tung, R. L. 2011. From a distance and generalizable to up close and grounded: Reclaiming a place for qualitative methods in international business research. Journal of International Business Studies, 42(5): 573-581.

Bouquet, C., \& Birkinshaw, J. M. 2008. Managing power in the multinational corporation: how lowpower actors gain influence. Journal of Management, 34(3): 477-508.

Brannen, M. Y., \& Doz, Y. 2012. Corporate languages and strategic agility: Trapped in your jargon or lost in translation? California Management Review, 54(3): 77-97.

Brannen, M. Y., Piekkari, R., \& Tietze, S. 2014. The multifaceted role of language in international business: Unpacking the forms, functions and features of a critical challenge to MNC theory and performance. Journal of International Business Studies, 45(5): 495-507.

Brueller, N. N., Carmeli, A., \& Markman, G. D. 2016. Linking Merger and Acquisition Strategies to Postmerger Integration A Configurational Perspective of Human Resource Management. Journal of Management, Published online before print February 10, 2016.

Buckley, P. J., Clegg, L. J., Voss, H., Cross, A. R., Liu, X., \& Zheng, P. 2018. A retrospective and agenda for future research on Chinese outward foreign direct investment. Journal of International Business Studies, 49(1): 4-23.

Capron, L., \& Guillén, M. 2009. National corporate governance institutions and post-acquisition target reorganization. Strategic management journal, 30(8): 803-833.

Chen, W., Ding, Y., Meyer, K. E., Wang, G., \& Xin, K. 2018. Global Expansion: The Chinese Way. London, UK: LID Publishing.

Collings, D. G. 2014. Integrating global mobility and global talent management: Exploring the challenges and strategic opportunities. Journal of World Business, 49(2): 253-261.

Collings, D. G., \& Isichei, M. 2018. The shifting boundaries of global staffing: integrating global talent management, alternative forms of international assignments and non-employees into the discussion. The International Journal of Human Resource Management, 29(1): 165-187.

Colman, H. L., \& Rouzies, A. 2018. Postacquisition Boundary Spanning: A Relational Perspective on Integration. Journal of Management, First Published March 5, 2018.

Cooke, F. L., Saini, D. S., \& Wang, J. 2014. Talent management in China and India: A comparison of management perceptions and human resource practices. Journal of World Business, 49(2): 225-235.

Cooke, F. L., Wu, G., Zhou, J., Zhong, C., \& Wang, J. 2018. Acquiring global footprints: Internationalization strategy of Chinese multinational enterprises and human resource implications. Journal of Business Research, Available online 26 April 2018.

Cui, L., \& Aulakh, P. 2018. Emerging economy multinationals in advanced economies. In R. Grosse, \& K. E. Meyer (Eds.), Oxford Handbook of Managing in Emerging Markets: In Press. Oxford: Oxford University Press. 
Cui, L., Meyer, K. E., \& Hu, H. W. 2014. What drives firms' intent to seek strategic assets by foreign direct investment? A study of emerging economy firms. Journal of World Business, 49(4): 488-501.

Doz, Y. L., \& Kosonen, M. 2010. Embedding strategic agility: A leadership agenda for accelerating business model renewal. Long range planning, 43(2): 370-382.

Eisenhardt, K. M. 1989. Building theories from case study research. Academy of Management Review, 14(4): 532-550.

Eisenhardt, K. M., \& Graebner, M. E. 2007. Theory building from cases: Opportunities and challenges. Academy of management journal, 50(1): 25-32.

Estrin, S., Meyer, K. E., \& Pelletier, A. 2018. Emerging Economy MNEs: How does home country munificence matter? Journal of World Business, 53(4): 514-528.

EY. 2015. Riding the Silk Road: China sees outbound investment boom. Outlook for China's outward foreign direct investment. Shanghai, China: Global Markets - EY Knowledge, Access on 15 Dec, 2016.

EY. 2018. Chinese firms pay record sums for European companies, especially in Germany and the UK: Accessed March, 31 2018. Zurich.

Felin, T., Foss, N. J., \& Ployhart, R. E. 2015. The microfoundations movement in strategy and organization theory. The Academy of Management Annals, 9(1): 575-632.

Gibbert, M., Ruigrok, W., \& Wicki, B. 2008. What passes as a rigorous case study? . Strategic Management Journal, 29: 1465-1474.

Gioia, D. A., Corley, K. G., \& Hamilton, A. L. 2013. Seeking qualitative rigor in inductive research notes on the Gioia methodology. Organizational Research Methods, 16(1): 15-31.

Glaser, B., \& Strauss, A. 1967. The discovery of grounded theory: Strategies for qualitative research. New York: Aldine Publishing Company.

Hansen, M. T. 2002. Knowledge networks: Explaining effective knowledge sharing in multiunit companies. Organization Science, 13(3): 232-248.

Haspeslagh, P. C., \& Jemison, D. B. 1991. Managing acquisitions: Creating value through corporate renewal. New York, NY: Free Press

He, S., Khan, Z., \& Shenkar, O. 2018. Subsidiary capability upgrading under emerging market acquirers. Journal of World Business, 53(2): 248-262.

Hobdari, B., Gammeltoft, P., Li, J., \& Meyer, K. E. 2017. The Home Country of the MNE: The Case of Emerging Economy Firms. Asia Pacific Journal of Management, 34(1): 1-17.

Huang, Y., Luo, Y., Liu, Y., \& Yang, Q. 2016. An investigation of interpersonal ties in interorganizational exchanges in emerging markets: A boundary-spanning perspective. Journal of Management, 42(6): 1557-1587.

Jackson, G., \& Deeg, R. 2008. Comparing capitalisms: understanding institutional diversity and its implications for international business. Journal of International Business Studies, 39(4): 540-561.

Johnson, K. L., \& Duxbury, L. 2010. The view from the field: A case study of the expatriate boundary-spanning role. Journal of World Business, 45(1): 29-40.

Junni, P., Sarala, R. M., Tarba, S. Y., \& Weber, Y. 2015. The Role of Strategic Agility in Acquisitions. British Journal of Management, 26(4): 596-616.

Kane, A. A., \& Levina, N. 2017. “Am I still one of them?": Bicultural immigrant managers navigating social identity threats when spanning global boundaries. Journal of Management Studies, 54(4): 540-577.

Khan, Z., Lew, Y. K., \& Sinkovics, R. R. 2015a. International joint ventures as boundary spanners: technological knowledge transfer in an emerging economy. Global Strategy Journal, 5(1): 48-68.

Khan, Z., Shenkar, O., \& Lew, Y. K. 2015b. Knowledge transfer from international joint ventures to local suppliers in a developing economy. Journal of International Business Studies, 46(6): 656-675.

Klitmøller, A., \& Lauring, J. 2013. When global virtual teams share knowledge: Media richness, cultural difference and language commonality. Journal of World Business, 48(3): 398-406. 
Klossek, A., Linke, B. M., \& Nippa, M. 2012. Chinese enterprises in Germany: establishment modes and strategies to mitigate the liability of foreignness. Journal of World Business, 47(1): 3544.

Klueter, T., \& Monteiro, F. 2017. How does performance feedback affect boundary spanning in multinational corporations? Insights from technology scouts. Journal of Management Studies, 54(4): 483-510.

Knoerich, J. 2010. Gaining from the global ambitions of emerging economy enterprises: An analysis of the decision to sell a German firm to a Chinese acquirer. Journal of International Management, 16(2): 177-191.

Kroon, D. P., Cornelissen, J. P., \& Vaara, E. 2015. Explaining employees' reactions towards a crossborder merger: the role of English language fluency. Management International Review, 55(6): 775-800.

Kumaraswamy, A., Mudambi, R., Saranga, H., \& Tripathy, A. 2012. Catch-up strategies in the Indian auto components industry: Domestic firms' responses to market liberalization. Journal of International Business Studies, 43(4): 368-395.

Levina, N., \& Vaast, E. 2005. The emergence of boundary spanning competence in practice: Implications for implementation and use of information systems. MIS Quarterly, 29: 335 363.

Li, H., Zhang, Y. A., \& Lyles, M. 2013. Knowledge Spillovers, Search, and Creation in China's Emerging Market. Management and Organization Review, 9(3): 395-412.

Li, S., Easterby-Smith, M., Lyles, M. A., \& Clark, T. 2016. Tapping the power of local knowledge: A local-global interactive perspective. Journal of World Business, 51(4): 641-653.

Liu, Y., Öberg, C., Tarba, S. Y., \& Xing, Y. 2018. Brand management in Mergers and Acquisitions: Emerging market multinationals venturing into advanced economies. International Marketing Review, 35(5): Forthcoming.

Liu, Y., Sarala, R. M., Xing, Y., \& Cooper, C. L. 2017. Human Side of Collaborative Partnerships: A Microfoundational Perspective. Group \& Organization Management, 42(2): 151-162.

Liu, Y., \& Vrontis, D. 2017. Emerging markets firms venturing into advanced economies: The role of context. Thunderbird International Business Review, 59(3): 255-261.

Liu, Y., \& Woywode, M. 2011. Chinese M\&A in Germany. In I. Alon, M. Fetscherin, \& P. Gugler (Eds.), Chinese International Investments: 212-233. Hampshire, UK: Palgrave Macmillan.

Liu, Y., \& Woywode, M. 2013. Light-touch Integration of Chinese Cross-Border M\&A: The Influences of Culture and Absorptive Capacity. Thunderbird International Business Review, 55(4): 469-483.

Luo, Y., Sun, J., \& Wang, S. L. 2011. Comparative strategic management: An emergent field in international management. Journal of International Management, 17(3): 190-200.

Luo, Y., \& Tung, R. L. 2007. International expansion of emerging market enterprises: A springboard perspective. Journal of International Business Studies, 38(4): 481-498.

Luo, Y., \& Tung, R. L. 2018. A general theory of springboard MNEs. Journal of International Business Studies, 49(2): 129-152.

Meyer, K. E. 2015. What is "strategic asset seeking FDI"? The Multinational Business Review, 23(1): 57-66.

Meyer, K. E., \& Peng, M. W. 2016. Theoretical foundations of emerging economy business research. Journal of International Business Studies, 47(1): 3-22.

Meyer, K. E., \& Xin, K. 2018. Managing Talent in Emerging Economy Multinationals: Challenges for Managers and Scholars. International Journal of Human Resource Management, Forthcoming: 1-29.

Michailova, S., \& Mustaffa, Z. 2012. Subsidiary knowledge flows in multinational corporations: Research accomplishments, gaps, and opportunities. Journal of World Business, 47(3): 383396.

Minbaeva, D., Pedersen, T., Björkman, I., Fey, C. F., \& Park, H. J. 2003. MNC knowledge transfer, subsidiary absorptive capacity, and HRM. Journal of International Business Studies, 34(6): 586-599. 
Minbaeva, D., \& Santangelo, G. D. 2018. Boundary Spanners and Intra-MNC Knowledge Sharing: The Roles of Controlled Motivation and Immediate Organizational Context. Global Strategy Journal, 8(2): 220-241.

Minbaeva, D. B., Pedersen, T., Björkman, I., \& Fey, C. F. 2014. A retrospective on: MNC knowledge transfer, subsidiary absorptive capacity, and HRM. Journal of International Business Studies, 45(1): 52-62.

Monteiro, F., \& Birkinshaw, J. 2017. The external knowledge sourcing process in multinational corporations. Strategic Management Journal, 38(2): 342-362.

Monteiro, L. F. 2015. Selective attention and the initiation of the global knowledge-sourcing process in multinational corporations. Journal of International Business Studies, 46(5): 505-527.

Monteiro, L. F., Arvidsson, N., \& Birkinshaw, J. 2008. Knowledge flows within multinational corporations: Explaining subsidiary isolation and its performance implications. Organization Science, 19(1): 90-107.

Mudambi, R., \& Navarra, P. 2004. Is knowledge power? Knowledge flows, subsidiary power and rent-seeking within MNCs. Journal of International Business Studies, 35(5): 385-406.

Mudambi, R., \& Swift, T. 2009. Professional guilds, tension and knowledge management. Research Policy, 38: 736 - 745.

Nag, R., \& Gioia, D. A. 2012. From common to uncommon knowledge: foundations of firm-specific use of knowledge as a resource. Academy of Management Journal, 55(2): 421-457.

Nair, S. R., Demirbag, M., \& Mellahi, K. 2015. Reverse knowledge transfer from overseas acquisitions: a survey of Indian MNEs. Management International Review, 55(2): 277-301.

Patriotta, G., Castellano, A., \& Wright, M. 2013. Coordinating knowledge transfer: Global managers as higher-level intermediaries. Journal of World Business, 48(4): 515-526.

Rabbiosi, L., \& Santangelo, G. D. 2013. Parent company benefits from reverse knowledge transfer: The role of the liability of newness in MNEs. Journal of World Business, 48(1): 160-170.

Raisch, S., \& Tushman, M. L. 2016. Growing new corporate businesses: From initiation to graduation. Organization Science, 27(5): 1237-1257.

Roberts, M. J. D., \& Beamish, P. W. 2017. The Scaffolding Activities of International Returnee Executives: A Learning Based Perspective of Global Boundary Spanning. Journal of Management Studies, 54(4): 511-539.

Rui, H., \& Yip, G. S. 2008. Foreign acquisitions by Chinese firms: A strategic intent perspective. Journal of World Business, 43(2): 213-226.

Santacreu-Vasut, E., Shenkar, O., \& Shoham, A. 2014. Linguistic gender marking and its international business ramifications. Journal of International Business Studies, 45(9): 11701178.

Sarala, R. M., Junni, P., Cooper, C. L., \& Tarba, S. Y. 2016. A sociocultural perspective on knowledge transfer in mergers and acquisitions. Journal of Management, 42(5): 1230-1249.

Schotter, A., \& Beamish, P. W. 2011. Performance effects of MNC headquarters-subsidiary conflict and the role of boundary spanners: The case of headquarter initiative rejection. Journal of International Management, 17: 243 - 259.

Schotter, A., Mudambi, R., Doz, Y., \& Gaur, A. 2017. Boundary spanning in global organizations. Journal of Management Studies, 54(4): 403-421.

Spigarelli, F., Alon, I., \& Mucelli, A. 2015. Chinese M \& A in Europe: Emerging market multinational in the heavy construction industry. Competitiveness Review, 25(4): 346-370.

Sun, S. L., Peng, M. W., Ren, B., \& Yan, D. 2012. A comparative ownership advantage framework for cross-border M\&As: the rise of Chinese and Indian MNEs. Journal of World Business, 47(1): 4-16.

Tenzer, H., \& Pudelko, M. 2017. The influence of language differences on power dynamics in multinational teams. Journal of World Business, 52(1): 45-61.

Tenzer, H., Pudelko, M., \& Harzing, A.-W. 2014. The impact of language barriers on trust formation in multinational teams. Journal of International Business Studies, 45(5): 508-535.

Tippman, E., Sharkey Scott, P., \& Parker, A. 2017. Boundary capabilities in MNCs: Knowledge transformation for creative solution development. Journal of Management Studies, 54(4): 455-482. 
Tippmann, E., Scott, P. S., \& Mangematin, V. 2014. Subsidiary managers' knowledge mobilizations: Unpacking emergent knowledge flows. Journal of World Business, 49(3): 431-443.

Tung, R. L. 2016. New perspectives on human resource management in a global context. Journal of World Business, 51(1): 142-152.

Tushman, M. L., \& Katz, R. 1980. External communication and project performance: An investigation into the role of gatekeepers. Management Science, 26(11): 1071-1085.

UNCTAD. 2016. World Investment Report 2016: Investor Nationality: Policy Challenges. New York and Geneva: United Nations.

Wang, G., Liu, X., \& Liu, Y. 2018. Role overload, knowledge acquisition and job satisfaction: An ambidexterity perspective on boundary-spanning activities of IT employees. The International Journal of Human Resource Management, Forthcoming.

Wang, S. L., Luo, Y., Lu, X., Sun, J., \& Maksimov, V. 2014. Autonomy delegation to foreign subsidiaries: An enabling mechanism for emerging-market multinationals. Journal of International Business Studies, 45(2): 111-130.

Weber, Y., \& Fried, Y. 2011. Guest Editors' Note: The role of HR practices in managing culture clash during the postmerger integration process. Human Resource Management, 50(5): 565-570.

Weber, Y., \& Tarba, S. Y. 2014. Strategic agility: a state of the art. California Management Review, 56(3): 5-12.

Williamson, P. J., \& Raman, A. P. 2011. How China reset its global acquisition agenda. Harvard Business Review, 89(4): 109-113.

Xing, Y., \& Liu, Y. 2015. Poetry and Leadership in Light of Ambiguity and Logic of Appropriateness. Management and Organization Review, 11(4): 763-793.

Xing, Y., \& Liu, Y. 2016. Linking leaders' identity work and human resource management involvement: the case of sociocultural integration in Chinese mergers and acquisitions. The International Journal of Human Resource Management, 27(20): 2550-2577.

Xing, Y., Liu, Y., Tarba, S., \& Cooper, C. L. 2017. Servitization in Mergers and Acquisitions: Manufacturing Firms Venturing from Emerging Markets into Advanced Economies. International Journal of Production Economics, 192(October): 9-18.

Xing, Y., Liu, Y., Tarba, S. Y., \& Cooper, C. L. 2016. Intercultural influences on managing African employees of Chinese firms in Africa: Chinese managers' HRM practices. International Business Review, 25(1): 28-41.

Yamao, S., \& Sekiguchi, T. 2015. Employee commitment to corporate globalization: The role of English language proficiency and human resource practices. Journal of World Business, 50(1): 168-179.

Yang, Q., Mudambi, R., \& Meyer, K. E. 2008. Conventional and Reverse Knowledge Flows in Multinational Corporations $\uparrow$. Journal of Management, 34(5): 882-902.

Zhao, Z. J., \& Anand, J. 2013. Beyond boundary spanners: The 'collective bridge' as an efficient interunit structure for transferring collective knowledge. Strategic Management Journal, 34(13): 1513-1530. 
Table 1. An overview of the four acquisition cases

\begin{tabular}{|c|c|c|c|c|c|c|}
\hline $\begin{array}{l}\text { Case } \\
\text { study }\end{array}$ & $\begin{array}{l}\text { Year of } \\
\text { acquisition }\end{array}$ & Industry & $\underline{\text { Transaction }}$ & $\frac{\text { Location of }}{\underline{\text { target }}}$ & $\begin{array}{l}\text { Ownership of } \\
\text { acquirer }\end{array}$ & $\frac{\text { Ownership of }}{\underline{\text { target }}}$ \\
\hline Case A & 2005 & $\begin{array}{l}\text { Machiner } \\
\text { y }\end{array}$ & $\begin{array}{l}\mathrm{CN} 1 \text { acquired DE1, manufacturer } \\
\text { of weaving machinery. }\end{array}$ & Germany & Private & Private \\
\hline Case B & 2012 & $\begin{array}{l}\text { Machiner } \\
\text { y }\end{array}$ & $\begin{array}{l}\mathrm{CN} 2 \text { acquired DE2, manufacturer } \\
\text { of heavy duty drive systems }\end{array}$ & Germany & $\mathrm{SOE}^{1}$ & Private \\
\hline Case C & 2014 & Retail & $\begin{array}{l}\mathrm{CN} 3 \text { acquired UK1, department } \\
\text { store group with over } 60 \text { stores }\end{array}$ & UK & Private & Private \\
\hline Case D & 2015 & $\begin{array}{l}\text { Financial } \\
\text { services }\end{array}$ & $\begin{array}{l}\mathrm{CN} 4 \text { acquired UK2, global markets } \\
\text { business and trading operations. }\end{array}$ & UK & $\mathrm{SOE}^{1}$ & Public-listed \\
\hline
\end{tabular}

Notes: 1) State-Owned Enterprise 
Table 2. Primary interviewees

\begin{tabular}{lcc}
\hline Informants & Number of interviews & Roles and positions \\
\hline$\underline{\text { Case A }}$ & 2 & Managing director, senior project manager, sales director, \\
Senior managers & 3 & European marketing manager, HR manager \\
Middle managers & & CEO, Director of Corporate Strategy, Vice Chairman \\
Case B & 3 & Director of Strategy and Business Development, Project \\
Senior managers & 4 & manager, Project Management director, Marketing manager \\
Middle managers & & \\
Case C & 2 & CFO, Vice President, HR manager, Marketing manager, \\
Senior managers & 3 & International Partnership manager \\
Middle managers & & \\
Case D & 3 & Chinese Chairman, Vice president, European managing \\
Senior managers & 2 & \\
Middle managers & & \\
\hline
\end{tabular}


Table 3. Indicative key aspects in semi-structured interview guidelines

\begin{tabular}{|c|c|c|}
\hline Pre-M\&A & M\&A transaction & $\begin{array}{l}\text { Post-integration } \\
\text { acquisition }\end{array}$ \\
\hline $\begin{array}{l}\text { - } \text { Motivation } \\
\text { - Contact and prior } \\
\text { relationship } \\
\text { - Situation and } \\
\text { access to } \\
\text { information }\end{array}$ & $\begin{array}{l}\text { - Decision-making } \\
\text { - Due diligence } \\
\text { - External support } \\
\text { - Internal competence }\end{array}$ & $\begin{array}{l}\text { - Integration management } \\
\text { - Knowledge transfer } \\
\text { - HRM practices } \\
\text { - Collaboration/ joint work } \\
\text { - Communication }\end{array}$ \\
\hline
\end{tabular}


Table 4. Reverse knowledge transfer and boundary spanners in Chinese overseas acquisitions

Reverse knowledge Second-order First-order categories Selective empirical evidence

\section{transfer mechanisms themes}

Enabling Ability

Cultural competence

of boundary spanners

"The reason that I'm running the European operation of this company is because I have spent quite a long time in China assisting the German governmental agency to manage technology transfer projects. I got contacted when I registered with VDMA Beijing, Verband Deutscher Maschinen- und Anlagenbauer [Association of German Machinery and Plant Engineers]. The German firm went bankrupt when the Chinese acquired, before I took the helm to steer the ship. I think you have to understand the culture before working with the Chinese.” (managing director in Case A)

"The hardest thing we find is the lack of consistency in comments or decisions.

What I mean by that is that the Chinese multiple departments do not speak to each other. So you get different instructions on the same subject from different departments. Those instructions also change over time. This means that, when you have put in lots of time, energy, and efforts, it is a waste to change instructions." (international partnership manager in Case C)

Language skills of boundary spanners
"When the Chinese colleagues say 'yes, yes', it does not mean 'yes' in terms of decision making. Rather, it means I understand or I accept this. But it does not mean that I agree with you on the opinion. But these are precisely these topics, since the Germans still have to learn a bit in the sense of cultural understanding. This is about the experiences not from text books, from a practical situation, how can I evaluate what just happened?" (senior German project manager in Case A)

"Although the financial product is global, however, the regulations in different capital markets are quite different. We need to communicate with the Chinese companies well the rules of the game. Knowing and being able to speak Chinese language is definitely a plus." (client relationship manager in Case D) 


\section{Enabling}

Power status

\section{Industry-specific \\ experience of}

boundary spanners

Advanced knowledge

on product and

marketing
Enabling

\begin{abstract}
Willingness to Light-touch collaborate
\end{abstract}

"The reason why they bought us was to take our concept, and open it in China.

What we do know is how to actually operate the business due to our vast industry experience, so they should be bringing together their knowledge of China and our knowledge of the business. Because that [way] you will have two complementary sides of the equation. The people who were involved in that transfer of knowledge between China and ourselves were those involved in design and product buying." (CFO in Case C)

"Financial products are sophisticated. The so-called "financial engineering" makes it even more complex. The Western financial markets are quite a few steps ahead of the Chinese financial sector, when we talk about financial derivatives. This experience gives an edge and leverage when working with our Chinese counterparts." (European managing director in Case D)

"The Chinese acquirer mostly produces construction engines for heavy duty truck. So, they produce high power engines for the construction industry. The Chinese acquirer is very interested in the hydraulics business. Therefore, they try to learn from our product development department, especially focussing on engines." (Director of Strategy \& Business Development in Case B)

"For Chinese companies to enter European market through acquisition, our deep knowledge about the market, especially the B-2-B marketing practice from our sales force can help the Chinese significantly to understand how to approach the

European market.” (European marketing manager in Case A)

"The raw materials from our Chinese mother company are cheaper compared to the available market prices. Thus, we'd be happy to explore the potential and work with our Chinese mother company." (sales director of German company in Case A)

"Our daily business operation remains highly independent. The Chinese company only gives some strategic advice. They do not intervene our business operations and decision-making process. We have high autonomy after the acquisition. (vice chairman in Case B) 
"The brand has been kept as strategic asset for Chinese companies. They want to leverage our brand to capture the rising middle-class in China and their growing purchasing power. Our brand has long history and we'd like to see it flourish in China. (marketing manager in Case C)

Market opportunity for target

Materializing

Collaborative HR practices
Team-based project development
"As for the engine business there, it was just in the beginning. They [Chinese] invested heavily in R\&D and tried to develop advanced technology that is applicable for construction industry. Now they [the German unit] have a chance to become a smaller Bosch Rexroth, they will have the money and resources now to do that. With the previous owner, it was not possible." (marketing manager of German company in Case B)

"The Chinese market looks attractive with promising opportunities. We need to think about how to develop products suitable for the Chinese market. The growing market attracts us to explore and capture market opportunities. The key idea is to expand the Chinese market for [the German company], not to focus on the European market." (European marketing manager in Case A)

"As we know, the Chinese financial market is still highly regulated. Foreign financial institutions cannot easily get there. You need permission from the government and regulators. After the acquisition, we formed strong bond with one of the largest Chinese state-owned commercial banks. This may open up the significant market opportunity for us." (Vice president in Case D)

"There are five projects defined after the closing to realize the synergy between us and the Chinese company. For these projects, we don't have any external integration manager, and I was heading those projects. We had five in the beginning, then these were expanded into seven projects. We have seven project teams, usually made up of Chinese and German led sub-teams. These project teams can share practices from both sub-teams, solve specific Chinese problems to foster knowledge exchange. It is much better than just buying the existing IP [intellectual property]. Because the IP might not work for the Chinese firm." (Director of Corporate Strategy in Case B) 
"Our collaborative projects with German and Chinese employees on board can help both sides to understand the opportunity. We encourage joint work to develop new products that address the Chinese market demand. This comes from team-based project collaboration." (CEO in Case B)

Trainings/ workshops between here [the UK] and China. The regulatory frameworks in the financial industry are country-specific. The regulations and practices in China are often not applicable here in the UK. Therefore, we need to learn from local people. This acquisition speeded up our global expansion, as we want to offer investment banking services. Workshops helped us to share knowledge and to learn from local practices as well." (The Chinese chairman in Case D)

"The project with WF [a city in China] works well. But we have language issues and culture issues. The management doesn't speak English. I cannot be the translator all the time. They hire translator in the end. I think that cross-cultural workshops are especially important." (project management director in Case B)

"We organize some training workshops combined with store visits for the Chinese employees. Such discussions seem quite helpful for both our side and Chinese to understand each other and think how we may capitalize our strength and expertise." (HR manager in Case C)

"I still don't know how to have a conversation with China. But the English speakers tend to be very young and inexperienced. So our primary contacts tend to be with very young and very inexperienced people. They will pass on messages from more senior people. But this means that there is no dialogue."." (vice president in Case C)

"It becomes obvious that many Chinese companies going abroad, making overseas investments. In order to engage with potential Chinese customers by using our financial expertise, we need to speak their language, mandarin Chinese! Therefore, employees from both UK and China need to interact and develop investment products, preferably using the client language." (assistant vice president in Case D) 
Communication by individuals at the interface
"In the end, language also reflects culture very strongly. Without a cultural understanding of how to run decision-making processes in China, you cannot understand or classify certain decision-making processes or measures. And if you cannot classify them, then discord or blockages can arise. So, from this perspective, I think it is for both sides. You see our colleague Karen from China is working here after studying in Germany, so we have the case that the Chinese learn the German language. But I think that the Germans will certainly have to learn a little Chinese to embrace the cultural differences. Language training is of particular relevance here." (HR manager in Case A)

"So, in terms of know-how transfer, we regularly send people from Germany, who then undertake tasks like training service teams, training the production in China. We also translate assembly instructions into Chinese. We have people in Chinacurrently, German employees from the areas of production and assembly — who are also actively involved in transferring know-how; i.e., in learning by doing." (Project manager in Case B) 
Figure 1. Data structure

First-Order Categories

A. Cultural competence of boundary spanners at target B. Language skills of boundary spanners at target

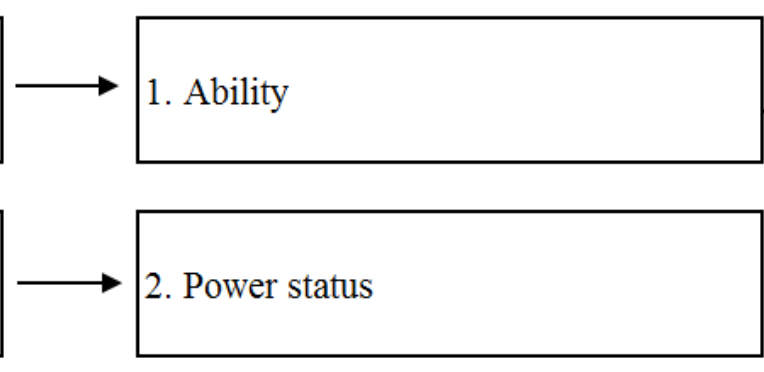

C. Industry-specific experience of boundary spanners at target

D. Advanced knowledge on product and marketing of target

Power status

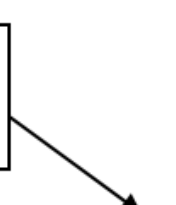

E. Light-touch integration at target after acquisition

F. Market opportunity provided by acquirer for target

3. Willingness to collaborate

G. Team-based project development between target and acquirer

H. Trainings and dedicated workshops for both target and acquirer

I. Language skills of employees in both target and acquirer

$\mathrm{J}$. Individuals at interface position in both target and acquirer to bridge

cultural difference through communication

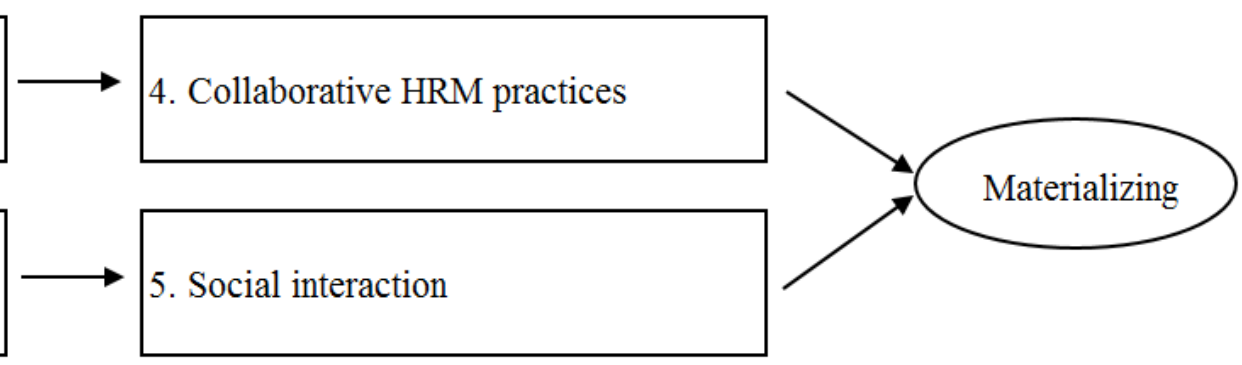


Figure 2. A conceptual framework on reverse knowledge transfer, boundary spanner and HRM practices

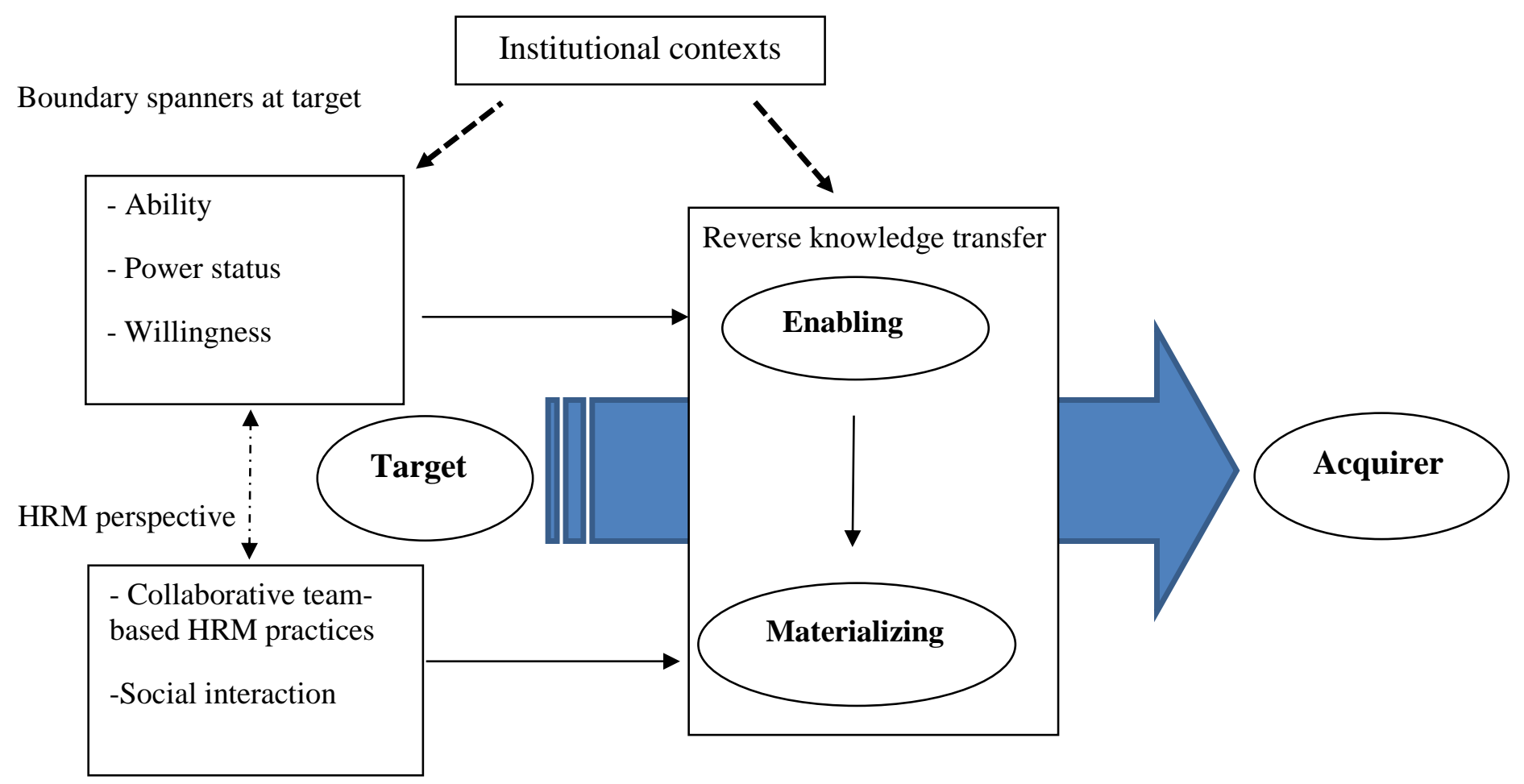

